
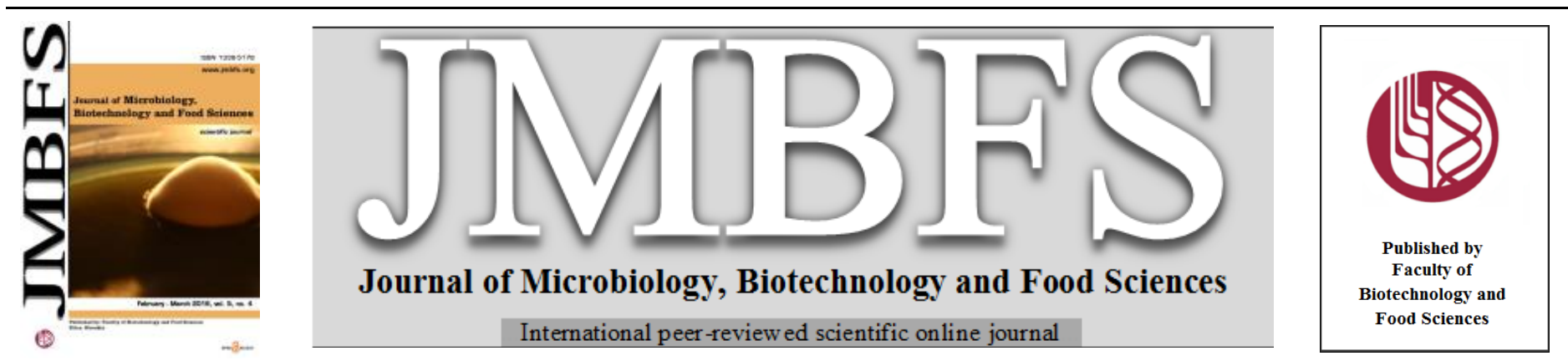

\title{
DETERGENT COMPATIBLE COLD-ACTIVE ALKALINE AMYLASES FROM CLAVISPORA LUSITANIAE CB13
}

\author{
Kamlesh Ranjan, Mansoor Ahmad Lone, Sanjay Sahay* \\ $\operatorname{Address(es):~}$ \\ Government Science \& Commerce College, Benazir, Bhopal (MP) India.
}

*Corresponding author: ss000@ rediffmail.com

doi: 10.15414/jmbfs.2016.5.4.306-310

\section{ARTICLE INFO}

Received 14. 5. 2014

Revised 22. 6. 2015

Accepted 22. 10. 2015

Published 1. 2. 2016

Regular article

OPEN $\partial_{\text {ACCESS }}$

\begin{abstract}
After two stages of screening, five environment isolates of yeasts showing amylolytic activity at alkaline $\mathrm{pH}$ and residual activity at cold temperatures were isolated from rotten vegetables. Based on $\mathrm{pH}$ and temperature robustness, amylases from $\mathrm{CB} 13$ were selected for further characterization. The enzymes from this yeast-isolate showed optimum activity at $\mathrm{pH} 11$ and temperature $40^{\circ} \mathrm{C}, 42 \%$ residual activity at $4^{\circ} \mathrm{C}$, no dependence on $\mathrm{Ca}^{2+}$ for activity and stability, resistance to EDTA and SDS, and amplification in activity in presence of $\mathrm{Mn}^{2+}$ and $\mathrm{Co}^{2+}$. The amylolytic activity was thermostable showing retention of 50\% of optimum activity after boiling for $30 \mathrm{~min}$. The enzymes retained nearly $80 \%$ of activity after exposing to various detergent components, and also to commercially available laundry detergents for $2 \mathrm{~h}$. The morphological, physiological and molecular characterization of the isolate CB13 led to its identification as Clavispora lusitaniae. This is the first report on the screening of detergent compatible $\alpha$-amylase with residual cold-activity from yeast isolated from rotten vegetables.
\end{abstract}

Keywords: Clavispora lusitaniae, Alkaline $\alpha$-amylases, Detergent compatible $\alpha$-amylases, Cold-active $\alpha$-amylase

\section{INTRODUCTION}

Microorganisms from nature have been found to contain a great variety of enzymes with tremendous variation in kinetic features, suitable for applications in diverse types of industries (Sidhu et al., 1997). Among various enzymes of industrial importance, $\alpha$-amylase (EC 3.2.1.1) holds top position accounting for approximately $25 \%$ of the enzyme market (Sidhu et al., 1997). Most importantly, they find applications in starch processing, brewing and sugar manufacturing, desizing in textile industries and detergent manufacturing (Pandey et al., 2000) The $\alpha$-amylases have been commercially produced applying bacteria belonging to the genus Bacillus such as B. amyloliquefaciens, B. stearothermophilus, B. subtilis and Bacillus licheniformis (Sivaramakrishnana et al., 2006).

Until now, there has been a wide interest in thermostable enzymes including thermostable $\alpha$-amylases for obvious reasons (Arikan, 2007; Carvalho et al., 2008). It is recently, the cold-active enzymes have started arousing much industrial interest because of potential economic benefits such as less energy investment, less chance of contamination (Cavicchioli et al., 2002) and higher quality of products (Sahay et al., 2012; Sahay et al., 2013) as a result of cold processing that goes with these enzymes. Thus for certain industries such as those of food, detergent etc, the cold active enzymes are now considered to be highly desirable (Nakagawa et al., 2002; Roohi et al., 2013; Sahay et al., 2013). One of the essential characteristics of cold-active enzymes viz., thermal instability is however a major hindrance in certain application such as detergent. Amylases are one of the highly used enzymes in the formulation of enzymatic detergent, and 90\% of all liquid detergents contain these enzymes (Hmidet et al., 2009).

The enzymes, amylases have many areas of applications; each application requires a special set of properties with respect to thermostability, $\mathrm{pH}$ profile, $\mathrm{pH}$ stability, $\mathrm{Ca}^{+2}$-independency etc. For example, amylases used in starch industry must be active and stable at low $\mathrm{pH}$ but those used in detergent industry must be active and stable at high $\mathrm{pH}, \mathrm{Ca}^{2+}$-independent and resistant to detergent components such as certain surfactants and oxidizing, chelating and bleaching agents (Carvalho et al., 2008; Chakraborty et al., 2012). It is, therefore, important to explore various sources to isolate such microbe as producing amylases with desirable features for specific application. The psychrotrophic microbes so far yielded very unstable amylases with hardly desirable features for application to detergent formulation (Roohi et al., 2013). The present paper describes isolation and partial characterization of cold active alkaline $\alpha$-amylases from a mesophilic natural yeast for application in detergent industry.

\section{MATERIALS AND METHODS}

\section{Site, sampling and source materials}

Various rotten vegetables were collected from the local market of Bhopal $\left(34.5^{\circ}\right.$ $36^{\circ}$ South latitude and $70^{\circ}-66.5^{\circ} \mathrm{Western}$ longitude) and carried to laboratory aseptically. For inoculums preparation, vegetables after cutting into pieces of about $1 \mathrm{~mm}^{2}$ with sterile knife were placed in flasks containing $10 \mathrm{ml}$ of sterile saline water $(0.1 \%)$ to a final concentration of $0.1 \mathrm{gm} \mathrm{ml}^{-1}$. The sample was shaken at $165 \mathrm{rpm}$ for $1 \mathrm{~h}$ at room temperature. Aliquot of $0.1 \mathrm{ml}$ size was spread on the surface of PDA (potato, glucose, agar) medium supplemented with chloramphenicol in the concentration of $1 \mathrm{mg} \mathrm{ml}^{-1}$. The plates were incubated at $25^{\circ} \mathrm{C}$ for $72 \mathrm{~h}$.

\section{Screening of extracellular amylase secreting isolates}

Medium used was a modified minimal synthetic medium (MM) containing ( $\mathrm{g} 1$ ${ }^{1}$ ); $\left(\mathrm{NH}_{4}\right)_{2} \mathrm{SO}_{4}-5, \mathrm{KH}_{2} \mathrm{PO}_{4}-1, \mathrm{NaCl}-0.1, \mathrm{MgSO}_{4}-0.5, \mathrm{CaCl}_{2}-0.01$, starch-0.1, Agar15, and pH adjusted to 7.0 (Sahay et al., 2013). The MM contained starch as sole carbon source to screen yeast isolates exhibiting constitutive amylolytic activity. The plates were incubated at $25^{\circ} \mathrm{C}$ for $48 \mathrm{~h}$. Amylase production was detected after flooding the plates with lugol's iodine (Arikan, 2008).

\section{Second screening}

In the second round of selection, the main parameters used were the rate of colony-growth and ability to grow at higher $\mathrm{pH}$. The medium used was $\mathrm{MM}$ with $\mathrm{pH}$ adjusted to 7.0 and 9.0 with $0.1 \mathrm{~N} \mathrm{NaOH}$. Since agar is not gelled at higher pHs properly, psyllium-gelled medium was also used (Sahay, 1999).

\section{Enzyme production}

One $\mathrm{ml}$ of $\log$ phase culture (density $\left.10^{6} \mathrm{1}^{-1}\right)$ from yeast growth medium $(0.67 \%$ yeast nitrogen base without amino acids and $2 \%$ glucose) was transferred to 250 $\mathrm{ml}$ conical flask containing $50 \mathrm{ml}$ of the yeast production medium $(0.67 \% \mathrm{YNB}$ and $2 \%$ starch). The growth was carried out at $25^{\circ} \mathrm{C}$ in a refrigerated shaking incubator (REMI/CIS 4) at $150 \mathrm{rpm}$, and was monitored by measuring $\mathrm{OD}_{600}$ of growth medium. Aliquots of $5 \mathrm{ml}$ sizes were withdrawn at $12 \mathrm{~h}$ intervals, cells were spun down at $5000 \mathrm{rpm}$ for $10 \mathrm{~min}$ and the supernatant was used to assay $\alpha$ amylases. 


\section{Partial purification}

After $72 \mathrm{~h}$ of growth, the culture was centrifuged at $5000 \mathrm{rpm}$ to remove cells The supernatant was saturated with ammonium sulphate to $40 \%, 50,60 \%$, and $80 \%$ level and precipitated proteins were collected by centrifugation at 10000 $\mathrm{rpm}$ at $4^{\circ} \mathrm{C}$ (REMI/CM12) for $10 \mathrm{~min}$. Maximum activity was observed in $50 \%$ fraction, that was thus dialysed against $100 \mathrm{mM}$ phosphate buffer $(\mathrm{pH} 7.0)$ at $4^{\circ} \mathrm{C}$, resuspended in the same buffer in minimum volume. The protein was further purified by DEAE chromatography as earlier (Roohi et al., 2013) and stored at $10^{\circ} \mathrm{C}$ until used.

\section{Enzyme assay}

The reaction-mix containing $1 \mathrm{ml}$ of $1 \%$ starch solution and $1 \mathrm{ml}$ of properly diluted enzyme (kept at $-10^{\circ} \mathrm{C}$ ) was incubated at $25^{\circ} \mathrm{C}$ for $30 \mathrm{~min}$. A $0.3 \mathrm{ml}$ aliquot of this solution was taken in another test tube, and equal volume of of 3,5dinitrosalicylic acid reagent was added to it. The solution was then boiled for $5 \mathrm{~min}$, and then cooled down to room temperature. It was diluted with $2.7 \mathrm{ml}$ of distilled water and, absorbance was measured at $540 \mathrm{~nm}$ using UV-Vis spectrophotometer. One unit of amylase activity was defined as the amount of enzyme that released $1 \mu \mathrm{M}$ of reducing sugar equivalent to glucose per min under the assay condition (Miller, 1954). The experiments were performed in three sets of duplicate cultures, and the mean value of enzyme activity was determined.

\section{Protein content}

Protein concentration was determined by the method described earlier (Lowry $\boldsymbol{e t}$. al., 1951) using bovine serum albumin as standard.

\section{Effect of $\mathbf{p H}$}

The effect of $\mathrm{pH}$ on the enzyme activity was determined by varying the $\mathrm{pH}$ of the reaction mixtures using the following buffers $(100 \mathrm{mM})$ : sodium acetate $(\mathrm{pH} 3.0$ $6.0)$, sodium phosphate ( $\mathrm{pH}$ 6.0-7.0), Tris- $\mathrm{HCl}(\mathrm{pH} 8.0-9.0)$ and glycine- $\mathrm{NaOH}$ ( $\mathrm{pH} \mathrm{10-11)} \mathrm{followed} \mathrm{by} \mathrm{assay} \mathrm{of} \mathrm{the} \mathrm{enzyme.} \mathrm{The} \mathrm{pH}$ stability was determined by pre-incubating the enzymes in different buffers for $1 \mathrm{~h}$. The residual activity was then assayed in $100 \mathrm{mM}$ sodium phosphate buffer $(\mathrm{pH} 7.0)$.

\section{Effect of temperature}

The effect of temperature on the enzyme activity was evaluated by measuring the amylolytic activity at different temperatures $\left(4^{\circ} \mathrm{C}, 25^{\circ} \mathrm{C}, 40^{\circ} \mathrm{C}, 50^{\circ} \mathrm{C}\right)$ in $100 \mathrm{mM}$ glycine- $\mathrm{NaOH}(\mathrm{pH} 11)$. The effect of temperature on stability of $\alpha$-amylases was determined by pre-incubating it in $100 \mathrm{mM}$ glycine- $\mathrm{NaOH}(\mathrm{pH} 11.0)$ at $50^{\circ} \mathrm{C}$ for $1 \mathrm{~h}, 2 \mathrm{~h}, 3 \mathrm{~h}, 4 \mathrm{~h}, 24 \mathrm{~h}, 48 \mathrm{~h}$ and $72 \mathrm{~h}$ followed by measuring its residual activity. The enzymes were also tested for their stability at boiling temperature by boiling for $1 \mathrm{~min}, 5 \mathrm{~min}, 10 \mathrm{~min}, 15 \mathrm{~min}, 20 \mathrm{~min}$ and $30 \mathrm{~min}$ followed by determining the residual activity.

\section{Effect of metal ions and chelator}

The effect of metal ions on amylases was determined by pre-incubation of the enzyme with various metal ions at a final concentration of $5 \mathrm{mM}$ in glycine$\mathrm{NaOH}$ buffer ( $\mathrm{pH} 11.0$ ), at $30^{\circ} \mathrm{C}$ for $30 \mathrm{~min}$ followed by their assay for the residual activity. Likewise, enzymes were pre-incubated with EDTA or SDS to the final concentration of $5 \mathrm{mM}$ and $1 \%(\mathrm{w} / \mathrm{v})$ respectively at $30^{\circ} \mathrm{C}$ for $30 \mathrm{~min}$, to see their effect on amylolytic activity. To examine stability, the incubation period of the enzymes with above factors was extended to $60 \mathrm{~min}$ followed by their assay for the residual activity. The activity of the enzymes alone in $100 \mathrm{mM}$ glycing- $\mathrm{NaOH}$ buffer (pH 11.0) was taken to be $100 \%$.

\section{Effect of detergent components}

The effect of important detergent ingredients such as surfactants (SDS, Tween-80 and Triton X-100), and oxidizing $\left(\mathrm{H}_{2} \mathrm{O}_{2}\right)$ and bleaching $\left(\mathrm{NaClO}_{3}\right)$ agents was studied by incubating enzyme $(50 \mu \mathrm{l})$ with $950 \mu \mathrm{l}$ of $1 \%$ of these reagents in 10 $\mathrm{mM}$ glycine- $\mathrm{NaOH}$ buffer $(\mathrm{pH} 11.0)$ for $1 \mathrm{~h}$ and $2 \mathrm{~h}$ at $40^{\circ} \mathrm{C}$ (Chakraborty et al. 2012) before assaying the enzyme as compared to the control without any additive.

\section{Effect of laundry detergents}

The detergent brands used were Surf Excel ${ }^{\circledR}$ (Hindustan Unilever LimitedMumbai, India) and Tide $\AA$ and Ariel ${ }^{\circledR}$ (Procter and Gamble Home Products Ltd). They were diluted in double distilled water to a final concentration of $7 \mathrm{mg}$ $\mathrm{ml}^{-1}$ to simulate washing conditions and heated at $100^{\circ} \mathrm{C}$ for 15 minutes to inactivate the enzymes that could be part of their formulation (Carvalho et al., 2008). The detergents were added to the reaction mixture and the reaction was carried out under standard assay conditions. To determine the stability of CB13 amylase in the presence of the different detergents, an amylase concentration of 1 $\mathrm{mg} \cdot \mathrm{ml}^{-1}$ was added in detergent solution and incubated at $50^{\circ} \mathrm{C}$ for $12 \mathrm{~h}$. Aliquots $(0.5 \mathrm{~mL})$ were taken at different time intervals and the residual activity determined at $20^{\circ} \mathrm{C}$ and $4^{\circ} \mathrm{C}$ and, compared with the control sample incubated at $50^{\circ} \mathrm{C}$ without any detergent (Carvalho et al., 2008).

\section{Taxonomic characterization of CB13}

Morphological and physiological characterizations of the most potential isolate, CB13 were carried out according to Barnet et al. (2000). All carbon sources except Arbutin, D-glucono-1,5-lactone, 2-keto-D-gluconate, 5-keto-D-gluconate, D-gluconate, D-glucuronate, D-glucarate and D-galactonate and nitrogen sources have been tested for their utilization by the yeast isolate CB13. For molecular characterization, DNA isolation from yeast was performed as per the protocol given earlier (Harzu, 2004). PCR amplification of D1/D2 region of the large ribosomal subunit was carried out applying primers NL-1 (5, GCATATCAATAAGCGGAGGAAAAG-3') and NL-4 (5' GGTCCGTGTTTCAAGACGG-3') and protocol given earlier (Kurtzman and Robnett, 1997). The purified $\sim 600$ bp PCR products were sequenced by automated DNA sequencer -3037xl DNA analyzer from Applied Biosystems using Big Dye ${ }^{\circledR}$ Terminator v3.1 cycle sequencing kit (Applied Biosystems). Sequence analysis software version 5.2 from applied biosystems was applied to align sequence data and generation of dendrogram. The sequences obtained for upper and lower strands were manually aligned before performing the analysis. BLASTN was used to compare this sequence to the non-redundant NCBI database to find the most similar sequence and were sorted by the E score. A representative sequence of 10 most similar neighbours was retrieved and multiple alignment was performed applying CLUSTAL W2 with the default settings. The evolutionary history was inferred using the UPGMA method (Tamura et al., 2011) and evolutionary analyses were conducted in MEGA5.

\section{RESULTS AND DISCUSSION}

\section{Isolation of alkalitolerant amylase producing yeasts}

In the first round, yeasts were isolated from various rotten vegetables showing constitutive amylolytic activity. In the second round, the selected yeasts were tested for their growth performance on alkaline medium and consecutively five yeasts showing constitutive amylolytic activity at $\mathrm{pH} 9$ were selected (Tab 1) for further study. Amylases have been reported from a number of yeasts (Wilson and Ingledew, 1982; Moranelli et al., 1982; DeMot and Verachtert, 1986; DeMot and Verachtert, 1987; Lefuji et al., 1996; Wanderley et al., 2004), there is hardly any report of their isolation from $C$. lusitaniae. Amylases are one of the most important industrial enzymes finding application in a variety of fields. Bacteria are the most important organisms serving the source of industria grade amylases so far (Sajedi et al., 2005), though enzymes with unique set of biochemical characteristics fit for specific applications have been reported from other classes of microbes (Sivaramakrishnan et al., 2006). As to the cold-active amylases, hardly any class of microbes other than bacteria of Antarctica origin has been explored (D'Amico et al., 2003). Therefore, cold-active amylases from these bacteria have become the model for biochemical study (D'Amico $\boldsymbol{e t}$ al., 2003) and, contemplating future applications. Likewise, alkaliphiles have been isolated from various sources earlier (Horikoshi, 1999). We are reporting coldactive amylolytic activity with utterly novel features from a yeast-isolate, C.lusitaniae $\mathrm{CB} 13$ isolated from rotten cabbage.

\section{Enzyme production}

During growth on agar plates containing starch as substrate, selected yeast isolates formed large starch digesting halos around their colonies as were evident from staining with iodine solution. This was an indication of the presence of amylolytic activity. The degradation of starch was accompanied by cell growth and amylase secretion in the production medium. The extracellular amylolytic activity increased during cell growth and reached maximum values at $96 \mathrm{~h}$ of incubation, which continued till $120 \mathrm{~h}$ (data not shown). The optimum enzyme activity at $96 \mathrm{~h}$ as shown by CF2, SP1, SP3, CB13 and PTC were 41.6, 13.92, 41.6, 46.7 and $11.11 \mathrm{U} / \mathrm{ml}$ for $0.1 \%$ substrate concentration respectively (Tab 1). 
Table 1 Maximum activity, optimum $\mathrm{pH}$ and optimum temperature of amylases isolated from selected yeast isolates

\begin{tabular}{|c|c|c|c|c|}
\hline Strains & Source & $\begin{array}{c}\text { Maximum } \\
\text { activity } \\
(\mathrm{U} / \mathrm{ml} / \mathrm{min})\end{array}$ & $\begin{array}{c}\text { Optimum } \\
\text { pH }\end{array}$ & $\begin{array}{c}\text { Optimum } \\
\text { temperature } \\
\left({ }^{\circ} \mathrm{C}\right)\end{array}$ \\
\hline CF2 & $\begin{array}{l}\text { Brassica } \\
\text { oleracea }\end{array}$ & 41.6 & 11 & 25 \\
\hline SP1 & $\begin{array}{l}\text { Spinacia } \\
\text { oleracea }\end{array}$ & 13.92 & 11 & 25 \\
\hline SP3 & $\begin{array}{l}\text { Spinacia } \\
\text { oleracea } \\
\text { Brassica }\end{array}$ & 41.6 & 11 & 25 \\
\hline CB13 & $\begin{array}{l}\text { oleracea var. } \\
\text { capitata }\end{array}$ & 46.17 & 11 & 40 \\
\hline PTC & Allium сера & 11.11 & 11 & 40 \\
\hline
\end{tabular}

Preliminary characterization of enzyme from selected yeast-isolates

In case of most strains, $0.1 \%$ substrate concentration was found to be optimum Only in case of CB13, a $0.2 \%$ substrate concentration was found to be optimum (data not shown).

The amylases from selected isolates were assayed at various pHs (Fig 1a). All the isolates seemed to yield alkaline amylases as the activity was found maximum at pH11. While $\mathrm{CB} 13$ seemed to be most $\mathrm{pH}$-sturdy isolate since its activity profile fell to only $55 \%$ while that of CF2 to $32 \%$ (Fig 1a). Overall, the amylases from all isolates showed one major peak activity at $\mathrm{pH} 11$ and a minor one at near $\mathrm{pH}$ 6.8. The activity of enzyme (amylases) was also assayed at $4^{\circ} \mathrm{C}, 25^{\circ} \mathrm{C}$ and $40^{\circ} \mathrm{C}$ and $50^{\circ} \mathrm{C}$. The amylases from all the isolates showed activity at all the temperatures though optimum temperature differ slightly, being $40^{\circ} \mathrm{C}$ for all of them except CF2 (Fig 1b). The activity from all the isolates was found to continue down to $4^{0} \mathrm{C}$. The percentage of amylases activity at $4^{0} \mathrm{C}$ varied from $84 \%$ (SP3) to 46 (SP1 and CB13) which is noteworthy.

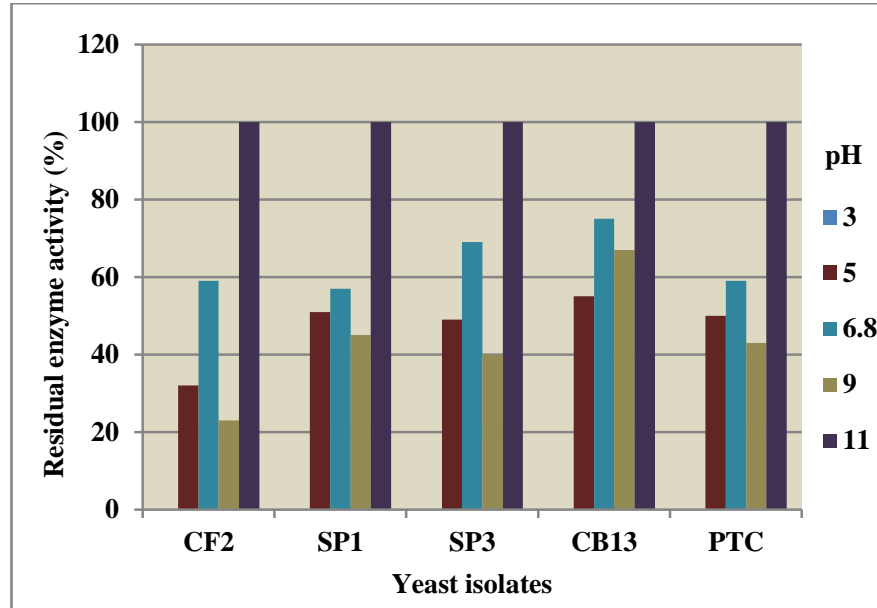

(a)

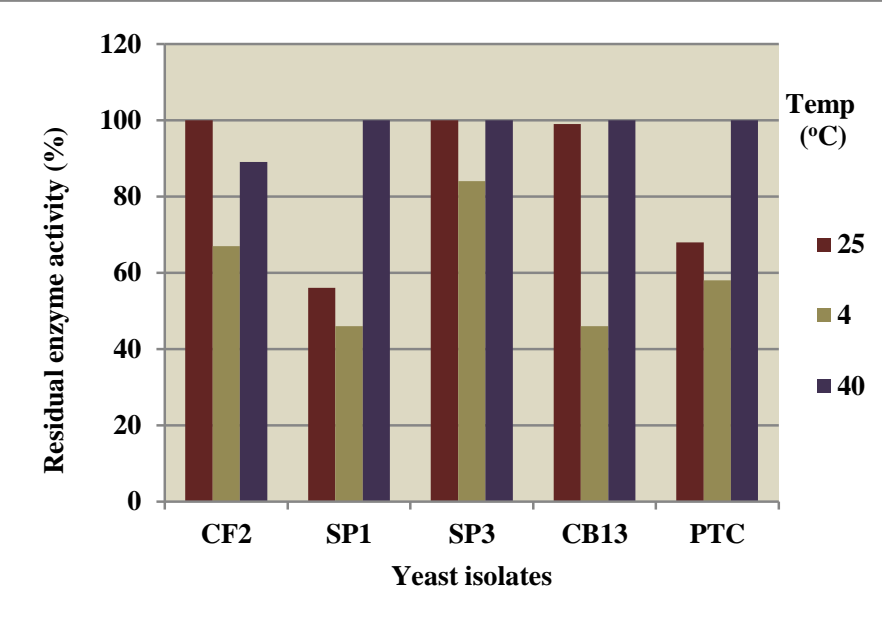

(b)

Figure 1 Effect of $\mathrm{pH}$ (a) and temperature (b) on the extracellular amylolytic activity in the partially purified extract from five selected yeast-isolates.

\section{Further characterization of amylase from CB13}

The enzymes could resist boiling for 1 min, during which a loss of only $10 \%$ of its activity was recorded. The enzymes retained $20 \%$ residual activity after 30 min of boiling (Fig 2).

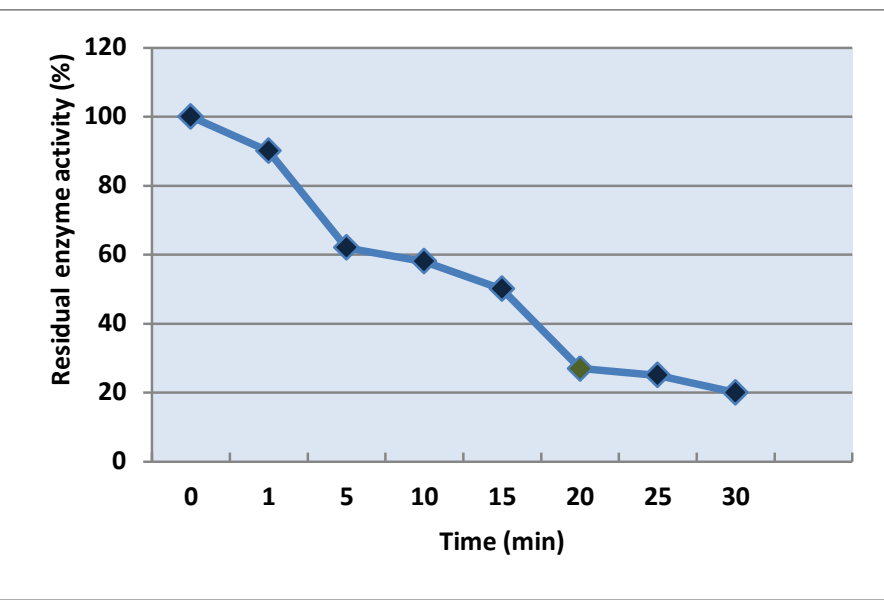

Figure 2 Effect of temperature (boiling temperature) on CB13 amylolytic activity

$\mathrm{Ca}^{2+}$ was found to have almost no effect on the enzymes immediately; though a little improvement of activity ( $8 \%$ ) was observed after $1 \mathrm{~h}$ of incubation with it Among inhibitors, $\mathrm{Cu}^{2+}$ had drastic effect reducing activity to $16 \%$ whilst $\mathrm{Fe}^{3+}$ reduced the activity marginally by $10 \%$. Among activators, $\mathrm{Mn}^{2+}$ was found to be the most effective one, followed by $\mathrm{Co}^{2+}$ and $\mathrm{Mg}^{2+}$ in that order. None of the metal ions tested was found to affect stability of the enzyme (Fig 3 ).

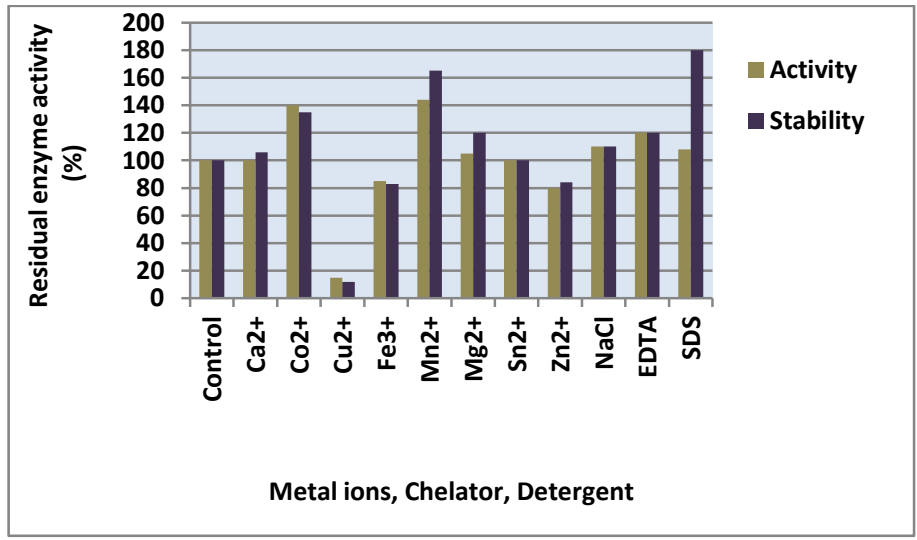

Figure 3 Effect of metal ions, chelator, salt and SDS on CB13 amylolytic activity

The activity of CB13 enzymes was found to be stimulated by salt, EDTA and SDS. SDS stimulated the activity by $80 \%$ during $1 \mathrm{~h}$ of its incubation with the enzymes. The enzymes showed $100 \%$ to more than $80 \%$ of residual activity after $2 \mathrm{~h}$ of incubation with selected detergent ingredients (Fig 4a). The enzymes exhibited retention of about $80 \%$ of their maximum activity till $6 \mathrm{~h}$ of incubation in presence of various detergents (Fig 4b) as compared to control; a restoration of the activity was also seen in next $6 \mathrm{~h}$ (Fig $4 \mathrm{~b})$.

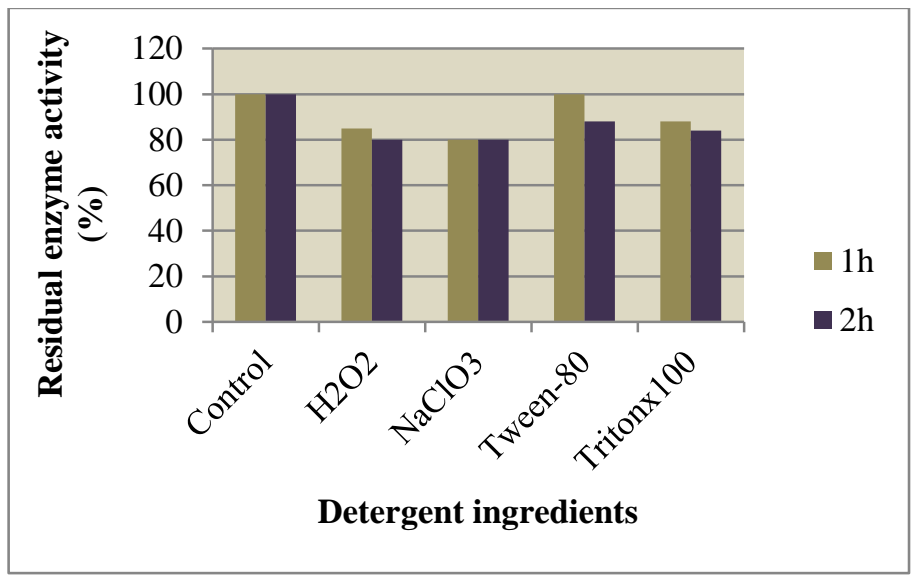

(a) 


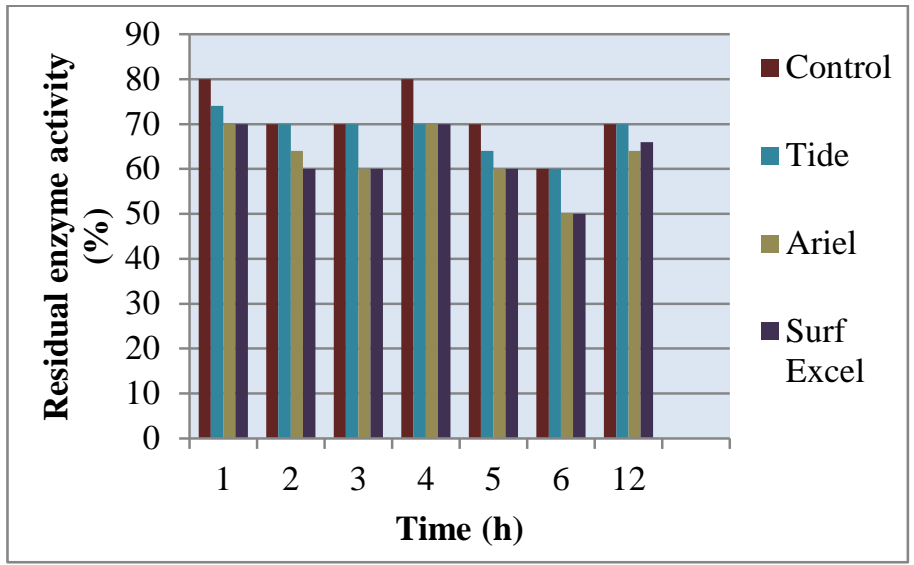

(b)

Figure 4 Effect of (a) detergent ingredients (components) and (b) laundry detergents on CB13 amylolytic activity.

The $\mathrm{CB} 13$ amylolytic activity showed optimum activity at $40^{\circ} \mathrm{C}$ at $\mathrm{pH} 11.0$ which is not in agreement with the data for the amylases from S. alluvius ATCC 26074 (DeMot and Verachtert, 1986), S. alluvius UCD 54-83 (DeMot and Verachtert, 1987) L. kononenkoae, C. antarctica CBS 6678 (DeMot and Verachtert, 1987) and C. flavus (Wanderley et al., 2004). The yeast enzymes retained $45 \%$ and $98 \%$ of their maximum activity at $4^{\circ} \mathrm{C}$ and $25^{\circ} \mathrm{C}$, a feature that may enable their application in various seasons and over larger geographical areas.

The enzyme is comparatively thermostable at lower temperatures, and also during boiling. It retains $20 \%$ residual activity after boiling for $30 \mathrm{~min}$, a feature which is remarkable not reported so far. Amylases have earlier been reported, but they required $\mathrm{Ca}^{2+}$ for their stability at higher temperature e.g., Bacillus sp. I-3, Bacillus sp. ANT-6, B. subtilis, Bacillus clausii BT- 21 and Bacillus licheniformis (Carvalho et al., 2008). This is thus the first report of yeast amylases showing thermostability at par with the bacterial's one, but independent of the presence of $\mathrm{Ca}^{2+}$ for activity or stability.

The optimal $\mathrm{pH}$ of the enzymes is 11.0 which is again a deviation from general acidic yeasts-amylases with optimum $\mathrm{pH}$ usually in the range of 4.0 and 6.0 (Kelly et al., 1985; Lefuji et al, 1996; Wanderley et al., 2004). Moreover, more than $50 \%$ of the activity of the enzymes was retained between $\mathrm{pH} 5.0$ to 11.0 which is something unusual, hardly reported so far in respect of amylolytic activity from any organism. This unusual $\mathrm{pH}$ sturdiness is an attractive feature and forms the basis for their various industrial applications. Alkalitolerant microbes have been evaluated as important sources of various bioactive substances (Horikoshi, 1999), hardly a few studies have been made with respect to alkalitolerant yeasts (Duckworth et al., 1996; Lisichkina et al., 2003).

As opposed to earlier reports, the enzymes were inhibited by only few metal ions studied. Among inhibitors of the enzymes, $\mathrm{Cu}^{2+}$ and $\mathrm{Fe}^{3+}$ ions are general inhibitors of amylases as reported earlier (Kelly $\boldsymbol{e t}$ al., 1985; Aguilar $\boldsymbol{e t}$ al. 2000; Wanderley et al., 2004).Likewise, $\mathrm{Mn}^{2+}$ and $\mathrm{Co}^{2+}$ were found to be very effective activators for these enzymes as for bacterial amylases (Bernharsdotter et al., 2005). None of the metal ions tested was found to reduce the stability, rather one of them $\left(\mathrm{Mn}^{+2}\right)$ was found to enhance the activity during incubation with it. The enzymes were found to be moderately stimulated and stabilized by $\mathrm{NaCl}$. The facts that the enzymes activity was only moderately stimulated but not stabilized by $\mathrm{Ca}^{+2}$ and that the activity was not affected by EDTA suggest that the enzymes are not metalloenzyme. In most of the cases, amylases have been found to be $\mathrm{Ca}^{+2}$ dependent metalloenzyme (Syed et al., 2009), though a few $\mathrm{Ca}^{2+}$ independent amylases have also been reported (Alva et al., 2007). The $\mathrm{Ca}^{2+}$ independent amylases are considered to be suitable for application in detergents. The amylolytic activity was most surprisingly enhanced by SDS indicating that hydrogen bonds may not play a key role in maintaining enzyme activity (Wang et al., 2005). The enzymes were not inhibited by $\mathrm{NaCl}$ indicating that it is dependent on $\mathrm{Cl}^{-1}$, a feature it shares with the Antarctica bacterium $P$. haloplanctis amylase and others (Numao et al., 2002). The unique characters of the enzymes were also manifested during incubation with various commercial detergents showing retention of about $80 \%$ of its maximum activity till $1 \mathrm{~h}$. The enzymes seem to be affected by the chemical environment of detergent to a little extent but yet, it showed much higher resistance to detergent as compared to earlier reported amylases (Carvalho et al., 2008). The biochemical properties of CB13 amylolytic activity, therefore, differ in a great deal from all the previously reported amylases (Sivaramakrishnan et al., 2006). It appears to be a coldactive nonmetallo-enzyme with a number of novel features. Preliminary biochemical characteristics suggest that these activities may find application in laundary detergent and textile industry. Since, amylases are one of the highly used enzymes in the formulation of enzymatic detergent (Hmidet et al., 2009), the enzymes may be commercially very important.

\section{Taxonomic characterization of CB13}

The yeast isolate CB13 was characterized morphologically and physiologically and assigned to the genus Clavispora lusitaniae. The colony was white in colour and butyrus in texture. Formations of pseudohyphae and budding cells (both unipolar and bipolar) were found. There was formation of 1-4 (typically four) ascospores per cell, each ascospore was smooth (Fig. b). The physiological data, when compared to CBS database with respect to $C$. lusitaniae, was found to be almost similar except in the utilization of starch as carbon source and Nitrate, Creatine, Creatinine and Tryptophan as nitrogen source. As against the CBS strains of $C$. lusitaniae, CB13 could utilize these metabolites as sole carbon or nitrogen source as the case may be.
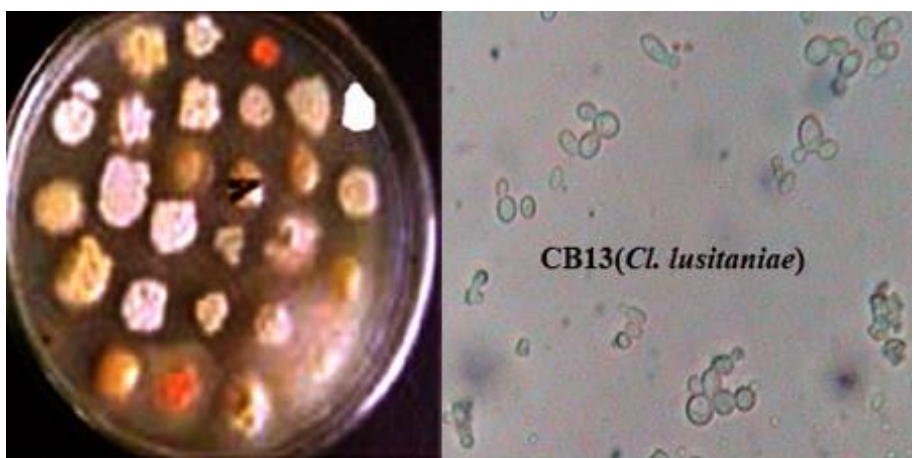

(a)

(b)

Figure 5 (a) Colonies of selected yeast-isolates including that of CB13 and (b) cells of CB13 with ascospores.

For molecular identification, the D1/D2 regions of 26s rDNA of CB13 was sequenced and the sequence was compared with those available in the NCBI database. The phylogenetic tree based on this sequence of CB13 along with those from ten the most closely related strains obtained from NCBI database showed $100 \%$ similarity to type and many of other strains of Clavispora lusitaniae (Fig.6), therefore, the isolate was so named. The nucleotide sequence has been deposited in the GenBank database under Accession number JNO91166

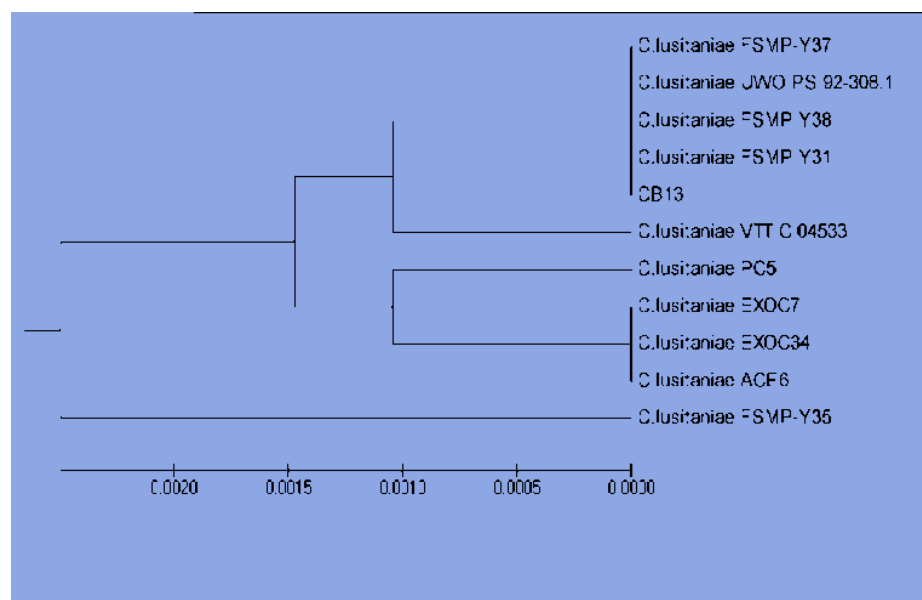

Figure 6 Phylogenetic relationship of CB13 with 10 closely related isolates retrieved from Genbank on the basis of D1/D2 sequences.

Earlier, C. lusitaniae has been reported to be associated with diseased lesions (Merz et al., 1990; Gargeya et al., 1992). Since the amylolytic activity of this strain is attractive, expression of this activity in an appropriate industrial microbe may be a safer way to exploit it (Steven and Pretorius, 1995). Physiological deviation in carbon and nitrogen utilization profile (Table 2) exhibited by CB13 as compared to those of other CBS strains of $C$. lusitaniae indicates the genetic flexibility of this taxon making it an adaptable organism. Moreover, this is the first report of stable, alkaline and cold-active amylolytic activity from yeast with potential application in detergent.

\section{Reproducibility of results}

All the experiments were carried out in triplicates and five times. Unless otherwise indicated, all values are average values calculated from three independently derived sets of data.

\section{CONCLUSION}

The yeast-isolates showing alkaline amylolytic activity were isolated from rotten vegetables. From among them, CB13 amylolytic activity was selected on the 
basis of $\mathrm{pH}$ and temperature robustness for further characterization. The enzymes of $\mathrm{CB} 13$ were thermostable, $\mathrm{Ca}^{2+}$ independent, non-metalloenzyme showing compatibility with surfactants, bleaches, oxidizing agents and local powder detergents. These features suggested the CB13 enzymes to be suitable candidate for detergent preparations. The yeast-isolate CB13 was identified as $C$. lusitaniae on the basis of morphological, physiological and molecular characteristics.

Acknowledgement: The research grant from University Grants Commission (India) to the corresponding author is herewith gratefully acknowledged.

\section{REFERENCES}

AGUILAR, G., MORLON-GUYOT, J., TREJO-AGUILAR, B., GUYOT, J.P. 2000. Purification and characterization of an extracellular $\alpha$-amylase produced by Lactobacillus manihotivorans LMG 18010T, an amylolytic lactic acid bacterium. Enzyme and Microbial Technology, 27, 406 413. http://dx.doi.org/10.1016/S0141-0229(00)00230-1

ARIKAN, B. 2008. Highly thermostable, thermophilic, alkaline, SDS and chelator resistant amylase from a thermophilic Bacillus sp. isolate A3-15. $\begin{array}{llll}\text { Bioresource } & \text { Technology, } & 99 & \text { (8), }\end{array}$ http://dx.doi.org/10.1016/j.biortech.2007.06.019

ALVA, S., ANUPAMA, J., SAVLA, J., CHIU, Y.Y., VYSHALI, P., SHRUTI, M., et al. 2007. Production and characterization of fungal amylase enzyme isolated from Aspergillus sp. JGI 12 in solid state culture. African Journal of Biotechnology, 6, 576-581.

BARNET, J.A., PAYNE, R.W., YARROW, D. 2000. Yeast, characterization and identification, $3^{\text {rd }}$ edition. Cambridge, U.K. : University Press, ISBN: 13: 978 0521573962.

BERNHARSDOTTER, E.C.M.J., NG, J.D., GARRIOTT, O.K., PUSEY, M.L. 2005. Enzymic properties of an alkaline chelator-resistant $\alpha$-amylase from an alkaliphilic Bacillus sp. isolate L1711. Process Biochemistry, 40, 2401-2408. http://dx.doi.org/10.1016/j.procbio.2004.09.016

CARVALHO, R.V.D.E., CÔRREA, T.L.R., DA SILVA, J.C.M., MANSUR L.R.C. DE OLIVEIRA, MARTINS, M.L.L. 2008. Properties of an amylase from thermophilic Bacillus sp. Brazilian Journal of Microbiology, 39, 102-107.

CAVICCHIOLI, R., SIDDIQUI, K.S., ANDREWS, D., SOWERS, K.R. 2002. Low temperature extremophiles and their applications. Current Opinion in Biotechnology, 13, 253-261. http://dx.doi.org/10.1016/S0958-1669(02)00317-8 CHAKRABORTY, C., RAUT, G., KHOPADE, A., MAHADIK, K., KOKARE C. 2012. Study on calcium ion independent amylase from haloalkaliphilic merine Streptomyces strain A3. Indian Journal of Biotechnology, 11, 427-437.

D’AMICO, S., MARX, JEAN-CLAUDE, GERDAY, C., FELLER, G. 2003. Activity-Stability Relationships in Extremophilic Enzymes. Journal of Biological Chemistry, 278 (10), 7891-7896. http://dx.doi.org/ 10.1074/jbc.M212508200

DE MOT, R., VERACHTERT, H. 1986. Secretion of $\alpha$-amylase and multiple forms of glucoamylase by the yeast Trichosporon pullulans. Canadian Journal of Microbiology, 32, 47-51. http://dx.doi.org/ 10.1139/m

DE MOT, R., VERACHTERT, H. 1987. Purification and characterization of extracellular $\alpha$-amylase and glucoamilase from the yeast Candida antarctica CBS 6678. European Journal of Biochemistry, 164, 643-654 http://dx.doi.org/ 10.1111/j.1432-1033.1987.tb11175.x.

DUCKWORTH, A.W., GRANT, W.D., JONES, B.E., VANSTEENBERGEN, R 1996. Phylogenetic diversity of soda lake alkaliphiles. FEMS Microbiological Ecology, 19, 181-191. http://dx.doi.org/ 10.1111/j.1574-6941; http://dx.doi.org/ 1996.tb00211.x

GARGEYA, I.B., PRUITT, W.R., SIMMONS, R.B., MEYER, S.A., AHEARN, D.G. 1990. Occurrence of Clavispora lusitaniae, the teleomorph of Candida lusitaniae. Journal of Clinical Microbiolgy, 28, 2224-2227.

GUPTA, R., GIGRAS, P., MOHAPATRA, H., GOSWAMI, V.K., CHAUHAN B. 2003. Microbial $\alpha$-amylase: a biotechnologicalperspective. Process Biochemistry, 38, 1599-1616. http://dx.doi.org/ 10.1016/S0032-9592 (03)00053$\underline{0}$

HADFIELD, T.L., SMITH, M.B., WINN, R.E., RINALDI, M.G., GUERRA, C. 1987. Mycoses caused by Candida lusitaniae. Review of Infectious Diseases 9:1006-1012.

HARJU, S. 2004. Rapid isolation of yeast genomic DNA: Bust n' Grab. BMC Biotechnology, 4, 8. http://dx.doi.org/10.1186/1472-6750-4-8

HORIKOSHI, K. 1999. Alkaliphiles: Some applications of their products for biotechnology. Microbiology and Molecular Biology Review, 63(4), 735-750.

KELLY, C.T., MORIARTY, M.E., FOGARTY, W.M. 1985. Thermostable extracellular $\alpha$-amylase and $\alpha$-glucosidase of Lipomyces starkeyi. Applied Microbiology and Biotechnology, 22, 352-358.

KURTZMAN, C.P., ROBNETT, C.J. 1997. Identification of clinically important ascomycetous yeasts based on nucleotide divergence in the 5 ' end of the largesubunit (26s) ribosomal DNA gene. Journal of Clinical Microbiology, 35, 12161223 .

LEFUJI, H., CHINO, M., KATO, M., IIMURA, Y. 1996. Raw-starch digesting and thermostable $\alpha$-amylase from the yeast Rhodotorula sp. S-2: purification, characterization, cloning and sequencing. Biochemical Journal, 318, 989-996.
LISICHKINA, G.A., BAB'EVA, I.P., SOROKIN, D.Y. 2003. Alkalitoleran yeasts from natural biotopes, Microbiology, 72, 695-698.

LOWRY, O.H., ROSEBROUGH, N., FARR, A., RANDALL, R. 1951. Protein measurement with the Folin phenol reagent. Journal of Biological Chemistry, 193, 265-275.

MERZ, W.G., KHAZAN, U., JABRA-RIZK, M.A., WU, LUNG-CHI, OSTERH, G.J. 1992. Strain Delineation and Epidemiology of Candida (Clavispora) lusitaniae Journal of Clinical Microbiology, 30, 449-454.

MILLER, G.L. 1959. Use of dinitrosalicylic acid reagent for determination of reducing sugar. Analytical Chemistry, 31, 426-428. http://dx.doi.org/10.1021/ac60147a030

MORANELlI, F., YAGUCHI, M., CALlEJA, B., NASIM, A. 1982 Purification and characterization of the extracellular $\alpha$-amylase activity of the yeast Schwanniomyces alluvius. Biochemistry Cell Biology, 65, 899-907. http://dx.doi.org/ 10.1139/o87-116

NUMAO, S., MAURUS, R., SIDHU, G., WANG, Y., OVERAL, C.M., BRAYER, G.D., WITHERS, S.G. 2002. Probing the Role of the Chloride Ion in the Mechanism of Human Pancreatic $\alpha$-amylase. Biochemistry, 41, 215-225. http://dx.doi.org/10.1021/bi0115636

PANDEY, A., NIGAM, P., SOCCOL, C.R., SOCCOL, V.T., SING, D., MOHAN, R. 2000. Advences in microbial amylases. Biotechnology and Applied Biochemistry, 31, 135-152.

ROOHI, KOODUS, M., SAIMA 2013. Cold-active detergent-stable extracellular $\alpha$-amylase from Bacillus cereus GA6: Biochemical characteristics and its perspectives in laundry detergent formulation. Journal of Biochemical Technology, 4(4), 636-644.

SAJEDI, R.H., NADERI-MANESH, H., KHAJEH, K., AHMADVAND, R. RANJBAR, B., ASOODEH, A., MORADIAN, F. 2005. A Ca-independent $\alpha$ amylase that is active and stable at low pH from the Bacillus sp. KR-8104 Enzyme and Microbial Technology, 36, 666-671 http://dx.doi.org/10.1016/j.enzmictec.2004.11.003

SAHAY, S. 1999. The use of psyllium as alternative gelling agent for microbial culture media. World Journal of Microbiology Biotechnology, 15, 733-735 http://dx.doi.org/10.1023/A:1008954128637

SINGH, P., HAMID, B., LONE, M.A., RANJAN, K., KHAN, A., CHAURSE, V.K., SAHAY, S. 2012. Evaluation of pectinase activity from the psychrophilic fungal strain Truncatella angustata BPF5 for use in wine industry. Journal of Endocytobiosis and Cell Research, 22, 57-61.

SAHAY, S., HAMID, B., SINGH, P., RANJAN, K., CHAUHAN, D., RANA R.S., CHAURSE, V.K. 2013. Evaluation of pectinolytic activities for oenological uses from psychrotrophic yeasts, Letters in Applied Microbiology, 57, 115-121. http://dx.doi.org/10.1111/lam.12081

SIDHU, G.S., SHARMA, P., CHAKRABART, T. et al. 1997. Strain improvement for the production of a thermostable $\alpha$-amylase. Enzyme and Microbial Technology, 21， 525-530. http://dx.doi.org/10.1016/S0141 0229(97)00055-0.

SIVARAMAKRISHNANA，S., GANGADHARAN，D., NAMPOOTHIRI K.M., SOCCOL, C.R., PANDEY, A. 2006. $\alpha$-Amylases from Microbial Sources. Food Technology and Biotechnology, 44 (2), 173-184.

SYED,D.G., AGASAR, D., PANDEY, A. 2009. Production and partial purification of $\alpha$-amylase from a novel isolate Streptomyces gulbargensis. Journal of Industrial Microbiology and Biotechnology, 36, 189-194 http://dx.doi.org/10.1007/s10295-008-0484-9.

STEYEN, A.J.C., PRETORIUS, I.S. 1995. Characterization of a novel $\alpha$ Amylase from Lipomyces kononenkoae and expression of its gene (LKA1) in Saccharomyces cerevisiae Current Genetics, 28, 526-533. http://dx.doi.org/ 10.1007/BF00518165

TAMURA, K., PETERSON, D., PETERSON, N., STECHER, G., NEI, M. KUMAR, S. (2011) MEGA5: Molecular Evolutionary Genetics Analysis using Maximum Likelihood, Evolutionary Distance, and Maximum Parsimony Methods. Molecular Biology and Evolution, 28, 2731 -2739. http://dx.doi.org/ 10.1093/molbev/msr121

WANDERLEY, K.J., TORRES, F.A.G., MORAES, L.M.P., ULHOA, C.J. 2004 Biochemical characterization of $\alpha$-amylase from the yeast Cryptococcus flavus FEMS Microbiology Letters, 231, 165-169. http://dx.doi.org/10.1016/S03781097(03)00955-8

WANG, Q.F., MIAO, J.L., HOU, Y.H., DING, Y., WANG, G.D., LI, G.Y 2005. Purification and characterization of an extracellular cold-active serine protease from the psychrophilic bacterim Colwellia sp. NJ341. Biotechnology Letters, 27, 1195-1198. http://dx.doi.org/10.1007/s10529-005-0016-x.

WILSON, J.J., INGLEDEW, W.M. 1982. Isolation and characterization of Schwanniomyces alluvius amylolytic enzymes. Applied and Environmental Microbiology, 44, 301-307. 